\title{
IMPLEMENTATION OF QUALITY MANAGEMENT SYSTEM ISO 9001:2008 IN IMPROVING TEACHER PERFORMANCE IN SMA DARUL ULUM 2 UNGGULAN BPPT JOMBANG
}

\author{
Rihatul Jannah \\ Sekolah Tinggi Keguruan dan IImu Pendidikan Syekh Manshur \\ Jalan Raya Labuan Km 5 Kadulisung Pandeglang \\ Ponsel : 082142001187 \\ Surel : eehat085@gmail.com
}

\begin{abstract}
Abstact
The ISO 9001:2008 quality management system is one of the implementation forms of total quality management (TQM) concept. This total quality management system requires an organization to have standards such as resource management standards, product realization, measurement and evaluation, and documentation system. The purpose of ISO 9001:2008 quality management systemis toimprovecustomer satisfaction by fulfilling customer requerements through complete facilities, profesional teachers, achievement improvement and many others. This research used qualitative approach with field research design. The results obtained that performance of theachers in SMA Darul Ulum 2 Unggulan BPPT Jombang has a good predicate and implementation of ISO 9001:2008 quality management system run well with the commitment of school principals and all the citizens of the school, and take the field. the ISO allows teachers to continue to learn and improve performance. That is also supported by commitment from high school princupals and high schoolcommunity by continuously improving the quality of work and there is a complete facility to facilitate school activities. so far, not many obstacles are heavy when schools use the ISO 9001:2008 management system, it just takes adjustment for each member to use this ISO management system.
\end{abstract}

Keywords: Teachers Performance, Implementation of ISO 9001:2008 Quality Management syatem

\section{PENDAHULUAN}

Dalam prespektif makro banyak faktor yang mempengaruhi mutu pendidikan, diantaranya faktor kurikulum, kebijakan pendidikan fasilitas pendidikan, aplikasi teknologi informasi dan komunikasi dalam dunia pendidikan, khususnya dalam kegiatan proses belajar mengajar di kelas, di laboratorium, dan di kancah belajar lainnya melalui fasilitas internet, aplikasi metode, strategi, dan

$$
\text { pendekatan pendidikan yang }
$$
mutakhir dan moderrn, metode evaluasi yang tepat, biaya pendidikan yang memadai, manajemen pendidikan yang dilaksanakan secara profesional, sumber daya manusia para pelaku pendidikan yang terlatih, berpengetahuan, berpengalaman, dan profesional. Juga sangat penting adanya standar nasional pendidikan yang menjadi norma acuan dalam penyelenggaraan pendidikan nasional 
yang mencakup strandar: isi, proses, kompetensi lulusan, standar pendidikan dan tenaga kependidikan, standar sarana dan prasarana, standar pengelolaan, pembiayaan dan standar penilaian pendidikan (Peraturan Pemerintah RI No.19:2005).

Dalam perspektif mikro atau tinjauan secara sempit dan khusus, faktor dominan yang berpengaruh dan berkontribusi besar terhadap mutu pendidikan ialah guru yang profesional dan guru yang sejahtera. Oleh karena itu, guru sebagai suatu profesi harus profesional dalam melaksanakan berbagai tugas pendidikan dan pengajaran, pembimbingan dan pelatihan yang diamanahkan kepadanya.

Guru sebagai pendidik merupakan tenaga profesional yang bertugas merancang dan melaksanakan proses pembelajaran, menilai hasil pembelajaran, melakukan bimbingan dan pelatihan serta melakukan penelitian dan pengabdian kepada masyarakat, terutama bagi para pendidik di jenjang pendidikan tinggi (UUSPN No. 20 2003). Oleh karena itu, para guru wajib mengembangkan kemampuan profesionalnya agar dapat meningkatkan kinerja dalam melaksanakan tugas, karena pendidikan di masa yang akan datang menuntut ketrampilan profesi pendidikan yang bermutu.

Akan tetapi Keadaan guru di Indonesia amat memprihatinkan. Kebanyakan guru belum memiliki profesionalisme yang memadai untuk menjalankan tugasnya sebagaimana disebut dalam pasal 39 UU No 20/2003 yaitu merencanakan pembelajaran, melaksanakan pembelajaran, menilai hasil pembelajaran, melakukan pembimbingan, melakukan pelatihan, melakukan penelitian dan melakukan pengabdian masyarakat.

Berdasarkan survei yang dilakukan Putera Sampoerna Foundation, sebanyak 54\% guru di Indonesia masih berkualitas rendah. Selain guru, jumlah anak Indonesia yang tidak melanjutkan sekolah sebanyak 1,5 juta anak. Sementara jumalah sekolah yang buruk masih sebesar 13,19\%. Kualitas guru di Indonesia masih perlu ditingkatkan (Indosesia.com. 2017).

Dalam upaya meningkatkan mutu sumber daya manusia disuatu negara, sudah seharusnya perlu ditingkatkan mutu pendidikan di 
negara tersebut dengan menerapkan standar dalam menyelenggarakan pendidikannya. Setiap penyelenggara pendidikan berkewajiban menetapkan kriteria minimal pada berbagai komponen strategis agar memenuhi standar mutu minimal sebagai modal dasar untuk meningkatkan mutu pendidikan yang ada. Peningkatan mutu pendidikan dalam satuan pendidikan atau sekolah selama ini terlalu difokuskan kepada fungsi dan peran guru.

SMA Darul Ulum 2 Unggulan BPPT Jombang sudah menerapkan sistem manajemen mutu ISO 9001:2008 sejak 2012 sampai sekarang, yang dengan menggunakan sistem manajemen mutu ISO 9001:2008 sudah memberikan dampak positif bagi semua masyarakat sekolah termasuk para guru, yang dengan adanya sistem manajemen mutu ISO 9001:2008 telah membuat para guru lebih disiplin untuk mendokumentasikan semua kegiatannya. Untuk mengetahui gambaran objektif kinerja guru dalam meningkatkan mutu pendidikan maka dilakukan penelitian tentang Implementasi Sistem Manajemen Mutu Iso 9001:2008 dalam Meningkatkan Kinerja Guru di SMA Darul Ulum 2 Unggulan BPPT
Jombang Cambridge Internasional School (CIS) ID 113.

Melihat dari penelitian sebelumnya tentang penerapan standar ISO 9001:2008 di SMK Negeri 1 Rambah, kinerja guru lebih optimal dalam proses belajar mengajar. Maka dari uraian di atas dapat dibuatkan rumusan maslaah untuk melengkap penelitian sebelumnya sebagai berikut ini: Bagaimanakah kinerja guru di SMA Darul Ulum 2 Unggulan BPPT Jombang Cambridge Internasional School (CIS) ID 113? Bagaimana implementasi sistem manajemen mutu ISO 9001:2008 terhadap peningkatkan kinerja guru di SMA Darul Ulum 2 Unggulan BPPT Jombang Cambridge Internasional School (CIS) ID 113? Apa faktor penghambat dan pendukung implementasi sistem manajemen mutu ISO 9001:2008 dalam meningkatkan kinerja guru di SMA Darul Ulum 2 Unggulan BPPT Jombang Cambridge Internasional School (CIS) ID 113?

Tujuan penelitian yang diarahkan sebagai berikut: Untuk mengetahui kinerja guru di J SMA Darul Ulum 2 Unggulan BPPT Jombang Cambridge Internasional School (CIS) ID 113. Untuk mengetahui implementasi sistem manajemen mutu ISO 9001:2008 
dalam peningkatkan kinerja guru di SMA Darul Ulum 2 Unggulan BPPT Jombang Cambridge Internasional School (CIS) ID 113. Untuk mengetahui faktor penghambat dan pendukung implementasi sistem manajemen mutu ISO 9001:2008 dalam meningkatkan kinerja guru di SMA Darul Ulum 2 Unggulan BPPT Jombang Cambridge Internasional School (CIS) ID 113.

\section{KAJIAN TEORETIK}

Manajemen Mutu (Quality Manajement) adalah keseluruhan metode untuk mengukur mutu dalam suatu organisasi meliputi prodrukjasa, kinerja, proses, dan sumber daya manusia. Manajemen mutu menggabungkan trilogi mutu untuk menyesuaikan semua program perbaikan yang meliputi tim kerja (Susanto 2016:02).

Manajemen mutu merupakan alternative baru dalam pengelolaan pendidikan yang lebih menekankan kepada kemandirian dan kreatifitas sekolah. Konsep ini diperkenalkan oleh Geri Effective School yang lebih menekan diri pada perbaikan proses pendidikan. beberapa indikator yang menunjukan karakter dari konsep manajemen ini antara lain: 1) lingkungan sekolah yang aman dan tertib; 2) Sekolah memiliki misi dan target mutu yang ingin dicapai; 3) sekolah memiliki kepemimpinan yang kuat; 4) adanya harapan yang tinggi dari personil sekolah (kepala sekolah, guru, staf lainnya termasuk siswa) untuk berprestasi; 5) adanya pengembangan staf sekolah yang terus menerus sesuai tuntunan IPTEK; 6) adanya pelaksanaan evaluasi yang terus menerus terhadap berbagai aspek akademik dan administratif dan pemanfaatan hasilnya untuk penyempurnaan/perbaikan mutu; dan 7) adanya komunikasi dan dukungan intensif dari orang tua murid masyarakat (Fathurrahman dan sulistyorini 2012:161).

Mutu dapat diukur dari kepuasan pelanggan atau pengguna pendidikan. Beranjak dari hal tersebut implementasi system manajemen mutu di lembaga pendidikan ada beberapa hal yang harus diperhatikan: 1) adanya perbaikan terus menerus (continius improvement) oleh pihak lembaga pendidikan atau sekolah kea rah peningkatan yang lebih baik; 2) adanya standar mutu yang bertujuan sebagai dasar atau landasan dalam pengembangan mutu agar lembaga pendidikan berusaha keras untuk mengembangkan lembaganya; 3) 
adanya perubahan budaya atau kultur (change of culture). Pada tahap ini lembaga pendidikan harus pandai dalam menyelesaikan budaya atau kultur yang ada pada lembaganya; 4) adanya perubahan organisasi yang mengarah pada upaya pengembangan dan peningkatan mutu pendidikan; dan 5) adanya usaha untuk mempertahankan hubungan baik dengan para pelanggan (zahroh 2014:93)..

Internasional Standardization Organization (ISO) adalah organisasi non-pemerintah yang beranggotakan badan-badan standarisasi nasional dari beberapa negara. ISO secara teknis dibentuk pada tahun 1986 dengan nama Techical Commetee 176 (TC176) atau lebih dikenal sebagai ISO/TC76 dan telah berhasil menyusun seri standar yang dapat diterima secara internasional.

Sampai saat ini, ISO 9001:2008 dianggap sebagai standar internasional terbaik untuk mengelola sistem manajemen mutu sehingga paling banyak diadopsi oleh berbagai organisasi termasuk lembaga pendidikan.

Delapan prinsip manajemen mutu yang menjadi landasan sistem manajemen mutu ISO 9001:2008 adalah: a) Fokus pada pelanggan, organisasi tergantung pada pelanggan karena itu manajemen organisasi harus memahami kebutuhan pelanggan sekarang dan akan datang dan giat berusaha melebihi ekspetasi pelanggan; b) Kepemimpinan, pemimpin organisasi menetapkan kesatuan tujuan dan arah organisasi. Mereka harus menciptakan dan memelihara lingkungan internal agar orang-orang dapat menjadi terlibat secara penuh dalam mencapai tujuantujuan organisasi; c) Keterlibatan orang-orang, orang pada semua tingkat merupakan faktor yang sangat penting dari suatu organisasi dan keterlibatan mereka digunakan untuk manfaat organisasi; d) Pendekatan proses, suatu hasil yang diinginkan akan tercapai secara lebih efektif apabila aktivitas dan sumber-sumber daya yang berkaitan dikelola sebagai proses; e) Pendekatan sistem terhadap manajemen, pengidentifikasi, pemahaman, dan pengelolaan dari proses-proses yang saling berkaitan sebagai suatu sistem akan memberikan kontribusi pada efektivitas dan efisiensi organisasi dan mencapai tujuan-tujuannya; f) Peningkatan terus-menerus, peningkatan terus-menerus dari kinerja organisasi secara keseluruhan harus menjadi tujuan tetapi dari 
organisasi; g) Pendekatan faktual dalam pembuatan keputusan, keputusan yang efektif adalah berdasarkan pada analisis data dan informasi; dan h) Hubungan pemasok yang saling menguntungkan, suatu organisasi dan pemasoknya adalah saling tergantung dan suatu hubungan yang saling menguntungkan akan meningkatkan kemampuan bersama dalam menciptakan nilai tambah (Listyo Prabowo 2009:57).

Langkah-langkah implementasi sistem manajemen mutu ISO 9001:2008 terdiri dari: a) Memutuskan untuk mengadopsi suatu standar sistem manajemen kualitas yang akan diterapkan, standar-standar sistem manajemen kualitas itu dipilih berdasarkan dan sesuai dengan kebutuhan pelanggan; b) Menetapkan suatu komitmen pada tingkat pemilihan senior dan organisasi; c) Menetapkan suatu kelompok kerja atau komite penagruh yang terdiri dari manajer-manajer senior; d) Menugaskan wakil manajer dan yang bertanggung jawab untuk menjamin bahwa persyaratan-persyaratan standar dari sistem manajemen kualitas itu diterapkan dan dipelihara; e) Manetapkan tujua-tujuan kaulitas dan implementasi system; f) Maninjau ulang sistem manajemen kualitas yang sekarang dapat memulai sautu audit sistem atau penilaian terhadap sistem manajemen kualitas yang ada; g) Mendefinisikan stuktur organisasi dan tanggung jawab; h) Menciptakan kesadaran kualitas pada semua tingkat dalam organisasi; i) Mengembangkan peninjauan ulang dari sistem manajemen kualitas dalam manual kualitas; j) Menyepakati dahwa fungsi-fungsi dan aktivitas dikendalikan oleh prosedur-prosedur; k) Mendokumentasikan aktivitas terperinci dalam prosedur operasional; I) Memperkenalkan dokumentasi; m) Menetapkan partisipasi karyawan dan pelatihan dalam system; dan $n$ ) Meninjau ulang dan melakukan audit sistem manajemen mutu (Purwadi:2012).

Tahapan implementasi sistem manajemen mutu ISO 9001:2008 dilakukan melalui: a) Keputusan dan komitmen manajemen, diperlukan untuk memastikan bahwa pelaksanaan dari penerapan ISO 9001 :2008 ini mendapatkan dukungan dan keterlibatan manajemen; b) Pelatihan dan sosialisasi ISO 9001:2008. Sistem manajemen mutu ISO 9001:2008 memerlukan keterlibatan seluruh warga karena itu diperlukan pelatihan. Materi pelatihan mencakup desain sistem dan 
pengembangan ISO 9001:2008 serta audit mutu internal dan eksternal; c) Pembentukan tim pelaksanaan ISO 9001:2008. Tim pelaksana ini dibentuk untuk menciptakan sinergitas tim guna peningkatan mutu kerja dan kepuasan pelanggan; d) Menyiapkan dokumen sistem mutu. yang disiapkan yaitu pedoman mutu, prosedur sistem mutu, instruksi kerja, formulir, dan dokumen pendukung lainnya; e) Uji coba sistem mutu. bersifat untuk mengimplementsikan sebagai uji coba sistem dokumen mutu yang telah disusun serta untuk melakukan penyesuian serta perbaikan atas penerapan sistem mutu tersebut; f) Audit mutu internal. berfungsi untuk memastikan bahwa sistem yang dikembangkan dapat dilaksanakan sepenuhnya dan memastikan keefektifan sistem tersebut agar dapat diidentifikasi peluang perbaikan; g) Sertifikat sistem manajemen mutu ISO 9001:2008: 1) Pemilihan badan sertifikas; 2) Pengajuan permohinan sertifikasi: 3) Penilaian awal (preassesment):

4) Sertifikat pemeliharaan; 5) Surveillance audit: dan 6) Penilaian ulang (Fathurrohman dan Sulistyorini 2012:197).

Keberhasilan implementasi sistem manajemen mutu ISO 9001:2008 dipengaruhi oleh beberapa faktor pendukung maupun faktor penghambat. Menurut ek dan cheng yang dikutip oleh dorothen w. ariani (2002:174) menjelaskan bahwa ada beberapa factor yang menjadi pendukung implementasi system manajemen mutu iso 9001:2008 pada suatu organisasi. Factor-factor tersebut antara lain, yaitu: a) Adanya komitmen dari manajemen puncak dan staf; b) Adanya pemahaman yang cukup tentang system manajemen mutu; b) Adanya budaya kerja mutu di dalam organisasi; c) Terjadinya komunikasi yang baik dari seluruh komponen organisasi baik internal maupun eksternal; e) Tersedianya dana.

Berdasarkan faktor-faktor pendukung diatas, maka faktor yang paling penting dalam penerapan iso 9001:2008 adalah adanya dukungan dan komitmen dari manajemen puncak dan staf. Tanpa adanya dukungan dan komitmen tersebut maka penerapan standar system manajemen mutu iso 9001:2008 tidak akan tercapai.

Berdasarkan faktor-faktor penghambat dalam implementasi system manajemen mutu iso 9001:2008, hendaknya suatu organisasi perlu menumbuhkan upaya untuk mengatasi hambatan-hambatan 
tersebut. Adapun upaya untuk mengatasi hambatan dalam penerapan system manajemen mutu iso $9001: 2008$ adalah sebagai berikut: a) Mengadakan infrastuktur untuk implementasi; b) Mengadakan pelatihan; c) Membuat indicator kinerja; d) Menyediakan sumber daya yang cukup (rudisuardi 2002:138).

Adanya penerapan system manajemen mutu iso 9001:2008 tentunya memberikan manfaat yang besar bagi suatu organisasi. Hal ini menunjukkan bahwa pentingnya penerapan system manajemen mutu iso 9001:2008 dalam suatu organisasi baik dalam dunia bisnis maupun dunia pendidikan.

Implementasi dari pelaksanaan iso 9001:2008 dapat juga menjadi salah satu cara untuk bertahan dan berkembang dalam situasi yang sulit, karena dengan menerapkan iso 9001:2008 berarti system manajemen mutu yang digunakan dalam suatu organisasi sama dengan pesaing di negara-negara maju.

Menurut Undang-Undang Republik Indonesia No. 14 Tahun 2005 tentang Guru dan Dosen:" guru adalah pendidikan profesional dengan tugas utama mendidik, mengajar, membimbing, mengarahkan, melatih, menilai dan mengevaluasi peserta didik pada pendidikan usia dini, pendidikan dasar, dan pendidikan menengah". Dalam Undang-Undang No. 14 Tahun 2005 dijelaskan bahwa: “ Guru mempunyai kedudukan sebagai tenaga profesional pada jenjang pendidikan usia dini, pendidikan dasar, dan pendidikan menengah, pada jalur pendidikan formal yang diangkat sesuai dengan paraturan perundang-undangan (Pasal 2 UU RI No. 14 : 2005).

Kinerja guru merupakan kemampuan seorang guru dalam melaksanakan tugas pembelajaran di sekolah dan bertanggung jawab atas peserta didik di bawah bimbingannya dengan meningkatkan prestasi belajar peserta didik. Oleh karena itu, kinerja guru itu dapat diartikan sebagai suatu kondisi yang menunjukan kemampuan seorang guru dalam menjalankan tugasnya di sekolah serta menggambarkan adanya suatu perbuatan yang ditampilkan guru dalam atau selama melakukan aktivitas pembelajaran (Supardi 2013:54).

\section{METODE PENELITIAN}

Jenis penelitian yang di gunakan dalam penelitian ini adalah penelitian kualitatif yang mengungkapkan suatu makna atau 
pengertian tertentu. Dalam penelitian ini, peneliti sebagai instrumen akan berperan aktif dalam menggali informasi mengenai standar kualitas manajemen kepala sekolah untuk dapat meningkatkan kinerja guru. Penelitian ini dimaksudkan untuk mengkaji dan menemukan fenomena apa yang dialami oleh subjek penelitian yaitu perilaku, persepsi, motivasi, tindakan, dan lain-lain (Moleong,2011:79).

Sumber data yang digunakan adalah data primer yang diperoleh dari kepala sekolah, ketua manajemen mutu ISO, guru, dab murid. Sedangkan data sekunder yaitu berupa dokumen dan arsip kenaikan lulusan setiap tahun di SMA Darul Ulum 2 Unggulan BPPT Jombang Cambridge Internasional School (CIS) ID 133. Teknik pengumpulan data menggunakan wawancara mendalam, dokumentasi, dan observasi. Teknik pemeriksaan dan keabsahan data penelitian ini yaitu triangulasi dan member check. Teknik analisis data menggunakan model analisis interaktif (Miles, 1992:22) adalah suatu proses analisis yang memiliki tiga komponen, yaitu reduksi data, sajian data, dan penarikan simpulan/verifikasi yang dilakukan secara simultan atau bersiklus. Dan setelah di analisis dan menghasilkan kesimpulan selanjutnya dimintakan (member check). Member check adalah proses pengecekan data yang diperoleh peneliti kepada pemberi data. Caranya peneliti melakukan diskusi dangan informan.

\section{HASIL PENELITIAN DAN PEMBAHASAN}

Dalam fokus yang pertama ini peneliti memfokuskan pada tiga kategori kinerja guru yaitu: 1) Perencanaan Pembelajaran, setiap guru di SMA Darul Ulum 2 Unggulan BPPT Jombang dituntut dan diwajibkan membuat RPP dan Silabus setiap pergantian semester. Dalam RPP dan silabus terdapat standar kompetensi, kompetensi dasar, indikator, bahan ajar, langkah pembelajaran, dan media pembelajaran dan masih ada lagi indikator-indikator yang lainnya.

Hal tersebut sejalan dengan Slamet PH (Sagala 2016) mengatakan bahwa setiap guru berkontribusi dalam mengembangkan kurikulum yang ada, mengembangkan mata pelejaran berdasarkan standar kompetensi (SK) dan kompetensi dasar (KD) merncanakan rencana pelaksanaan pembelajaran (RPP) berdasarkan silabus yang telah 
dikembangkan, merancang manajemen pembelajaran dan manajemen kelas, melaksanakan pembelajaran yang pro-perunahan (aktif, kreatif, inovatif, eksperimentif, efektif, dan menyenangkan). Menilai hasil belajar peserta didik secara otentik, membimbing peserta didik dalam berbagai aspek, misalnya pelajaran, kepribadian, bakat, minat, karir, dan mengembangkan profesionalisme diri sebagai guru. Dalam undang-undang Nomor 41 dijelaskan bahwa perencanaan proses pembelajaran meliputi silabus dan RPP yang memuat identitas mata pelajaran, standar kompetensi (SK), kompetensi dasar (KD) indikator pencapaian kompetensi tujuan pembelajaran, materi ajar, alikasi waktu, materi pembelajaran, kegiatan pembelajaran, penilaian hasil bekajar, dan sumber belajar.

Dan di SMA Darul Ulum 2 Unggulan BPPT Jombang kinerja guru terkontrol dengan baik terbukti dengan adanya rapot bagi setiap guru untuk mengevaluasi hasil kinerja guru selama di sekolah.

Dalam mengimplementasikan sistem manajemen ISO 9001:2008 di butuhkan kerja sama antar pemimpin dan para staf yang terlibat dalam sistem manajemen sekolah diantaranya adalah kepala sekolah, wakil kepala sekolah, guru, staf, siswa, wali murid, dan masyarakat. Penerapan sistem manajemen mutu di SMA Darul Ulum 2 Unggulan BPPT Jombang sangat membantu untuk meningkatkan pelayanan pendidikan dari semua sektor pendidikan yang ada di sekolah itu. Dan dibutuhkan komitmen dan dukungan penuh dari kepala sekolah atau pemimpin. Soepardi dalam E. Mulyasa mendefinisikan kepemimpinan sebagai kemampuan untuk menggerakan, mempengaruhi, memotivasi, mengajak, mengarahkan, menasihati, membimbing, menyuruh, memerintah, agar manusia sebagai media manajemen mau bekerja dalam mencapai tujuan administrasi secara efektif dan efisien (Mulyasa 2007:10). Implementasi sistem manajemen mutu ISO 9001:2008 telah dimulai sejak tahun 2012 karena dipercaya menuasai dalam dunia pendidikan. sertifikat yang berhasil diperoleh menunjukan bahwa seluruh aktivitas yang dilaksanakan di SMA Darul Ulum 2 Unggulan BPPT Jombang dikelola secara profesional sesuai dengan standar internasional yang berlaku, akan tetapi hal ini bukanlah akhir dari perjuangan karena sertifikat hanya berlaku 3 tahun 
sehingga dapat diperpanjang atau bahkan dicabut sesuai hasil audit setiap tahunnya. Dalam pelaksanaan sistem manajemen mutu ISO 9001:2008 mengacu pada sasaran mutu, pencapaian sistem manajemen mutu ISO 9001:2008 di SMA Darul Ulum 2 Unggulan BPPT Jombang memiliki nilai tambah diantaranya adalah naiknya kepercayaan masyarakat untuk menyekolahkan anak-anaknya di sekolah Darul Ulum 2, siswa/siswi lulusan darul ulum memiliki kualitas lulusan baik dan bisa bersaing di dunia pendidikan akademik di kampus-kampus terkenal baik dalam negeri maupun luar negeri. Kedisiplinan para staf dan semua kegiatan terakomodasi dengan rapih, seperti pendapat Purwadi bahwa sekolah yang menerapkan sistem manajemen mutu ISO 9001:2008 akan memiliki keunggulan pada sistem administrasi pada semua bagian di sekolah, hal ini bisa terjadi karena pada sistem manajemen mutu ISO sekolah wajib untuk mengendalikan kearsipan, dengan menggunakan SMM ISO sekolah juga memiliki prosedur kerja yang operasional dan terukur sehingga tidak terjadi tumpang tindih kewenangan dan kewajiban di sekolah.
Dengan adanya sistem manajemen mutu di SMA Darul Ulum 2 Unggulan BPPT Jombang memudahkan setiap guru untuk berkembang dan belajar ilmu baru, administrasi lebih tertata dan membantu mendisiplinkan dan mengarsipkan dokumen sehingga sistem manajemen mutu ISO 9001:2008 di sekolah SMA Darul Ulum 2 Unggulan BPPT Jombang bisa membantu meningkatkan kinerja guru. Penerapan ISO 9001:2008 akan dapat memberikan nilai tambah pada sekolah salah satunya adalah akan bertambah baik administrasi sekolah pada semua sub dan bidang. hal ini bisa terjadi karena ISO 9001:2008 wajib untuk mengendalikan kearsipan. Untuk mengetahui sejauh mana implementasi sistem manajemen mutu meninjau sejauhmana rancangan yang dibuat berjalan dengan baik di lapangan. Audit ini ada dua model yang pertama audit internal dan audit yang kedua yaitu audit eksternal. Audit internal adalah dilakukan di dalam yaitu yang mengaudit adalah pihak sekolah itu sendiri dengan memakai sistem silang yang dilakukan dua kali dalam setahun. Dan audit eksternal dilakukan oleh tim audit dari lembaga ISO itu sendiri satu tahun sekali. 
Menurut Sugeng LB ada 2 macam audit yang dilakukan a) audit internal yaitu audit yang dilakukan oleh pihak dalam; b) audit eksternal yaitu audit dari lembaga sertifikat yang menangani organisasi sistem manajemen mutu yang memenuhi syarat ISO 9001:2008. Dalam buku Purwadi audit mutu berfungsi untuk memastikan bahwa sistem yang dikembangkan dapat dilaksanakan dengan sepenuhnya dan memastikan keefektifan sistem tersebut agar dapat diidentifikasi peluang perbaruan.

Faktor pendukung tersebut ialah a) Adanya komitmen dari seluruh warga sekolah. Komitmen merupakan persyaratan dasar dari proses penerapan sistem manajemen mutu ISO 9001:2008 yang akan memberikan motivasi dan panduan untuk melaksanakannya. Komitmen harus di tunjukan oleh setiap tingkatan dan personal yang ada dalam organisasi. Pimpinan manajemen organisasi bertanggung jawab untuk menunjukan komitmennya sebagai pemeran utama dalam proses penerapan SMM ISO 9001:2008, yang kemudian diturunkan kepada seluruh tingkat dalam organisasi dimana pada masing-masing fungsi yang dituntut pula untuk membuat komitmen yang sama dengan komitmen dari pimpinan manajemen. Kegagalan untuk penerapan standar SMM ISO 9001:2008 adalah tidak adanya komitmen dari pelaksana sistem manajemen mutu yang diteteapkan. Komitmen ditunjukan dengan keikutsertaan yang aktif dan memahami arah tujuan diterapkannya SMM ISO 9001:2008 di dalam organisasi serta menyepakati sistem manajemen mutu yang telah ditetapkan bersama.

b) Fasilitas yang lengkap. Sarana dan prasarana lembaga pendidikan sangat menunjang pekerjaan guru. Kita bisa membandingkan antara guru yang dilengkapi sarana prasarana yang memadai dengan guru yang tidak dilengkapi sarana dan prasarana yang memadai. Guru yang dilengkapi dengan sarana prasarana yang memadai menunjukan kinerja yang lebih baik dari pada guru yang tidak dilengkapi sarana prasaran. Seperti halnya di SMA Darul Ulum 2 Unggulan BPPT Jombang sudah memfasilitasi siswanya yang terdiri dari sarana prasarana pendidikan meliputi: lab. komputer, lab. Multimedia, lab. Fisika, lab. kimia, lab. biologi, lab. bahasa, ruang kelas berbasis ICT, ruang kelas kesenian, sarana olah raga, mobil sekolah, 
ruang kegiatan siswa dan masih ada lagi sarana yang lainnya.

Sesuai dengan undangundang peraturan pemerintah republik Indonesia No.19 tahun 2005 tentang Standar Nasional Pendidikan pasal 42 "setiap satuan pendidikan wajib memiliki prasarana yang meliputi lahan, ruang kelas, ruang pimpinan satuan pensisikan, ruang pendidik, ruang tata usaha, ruang perpustakaan, ruang labolatorium, ruang bengkel kerja, ruang unit produksi, ruang kantin, instalasi daya dan jasa, tempat olahraga, tempat beribadah, tempat bermain, tempat berkreasi, dan ruang lain yang diperlukan untuk menunjukan pembelajaran yang teratur dan berkelanjutan.

Sedangkan faktor penghambat implementasi sistem manajemen mutu ISO 9001:2008 dalam meningkatkan kinerja guru SMA Darul Ulum 2 Unggulan BPPT Jombang CIS ID 113 yaitu pelaksanaan sistem manajemen mutu ISO 9001:2008 yang tidak banyak menemukan penghambat, hanya saja butuh penyesuaian dengan sistem yang baru, atau butuh penyesuaian antara semua pekerja dan kegiatan yang harus terdokumentasi.
Dari penelitian sebelumnya ada banyak persamaan yaitu memberikan suatu coherent set dari standar sistem manajemen mutu. Artinya keempat standar tersebut saling berkaitan secara logis dan saling melengkapi. Pada bulan Mei 2008 ISO 9001:2000 diperbaharui menjadi ISO 9001:2008. Perubahan yang dilakukan dari versi 2000 ke versi 2008 memang tidak sedrastis ketika dilakukannya perubahan dari versi 1994 ke versi 2000. Namun demikian, tetap terdapat banyak hal penting dalam perubahan versi tersebut, utamanya berkaitan dengan penyesuaian terhadap teknologi informasi dan penggunaan tenaga kerja luar. Organisasi yang telah memperoleh MMS ISO 9001:2000 harus melakukan update pada versi 2008 ini selambatlambatnya pada bulan November 2010. Sampai saat ini, ISO 9001:2008 dianggap sebagai standar internasional terbaik untuk mengelola sistem manajemen mutu sehingga paling banyak diadopsi oleh berbagai organisasi termasuk lembaga pendidikan.

\section{SIMPULAN}

Simpulan dari penelitian dapat dijabarkan sebagai berikut. Pertama, Kenaikan kinerja guru dilihat dari tiga factor yaitu 1) membuat perencanaan 
pembelajaran; 2) kedisiplinan; dan 3) guru yang berkualitas. Kinerja guru mempunyai predikat yang baik. Karena didalam melaksanakan tugasnya guru ditinjau oleh wakil kepala sekolah untuk menilai dan mengawasi kerja guru. Kedua, implementasi system manajemen mutu ISO 9001:2008 terhadap peningkatan kinerja guru di SMA DArul Ulum 2 Unggulan BPPT Jombang CIS ID 113 berjalan dengan baik dengan adanya komitmen kepala sekolah dan seluruh warga sekolah dan terjun ke lapangan. Dan dengan adanya ISO memudahkan para guru untuk terus belajar dan meningkatkan kinerja. Ketiga, factor pendukung: komitmen dari kepala sekolah dan masyarakat sekolah yang tinggi dengan terus menerus melakukan perbaikan kualitas kerja. Dan adanya fasilitas yang lengkap untuk mempermudah kegiatan sekolah. Factor penghambat: tidak banyak hambatan yang berat ketika sekolah menggunakan system manajemen ISO 9001:2008 hanya saja butuh penyesuaian bagi setiap anggota untuk menggunakan system manajemen ISO ini.

Diharapkan adanya penelitian ini bisa meningkatkan system manajemen mutu kenerja para guru baik di sekolah SMA Darul Ulum dan guru pada umumnya

\section{DAFTAR PUSTAKA}

Anwar, Muhammad Rofiq. "Implementasi Sistem Manajemen Mutu Iso 9001.2008 di MAN 3 Seleman (Upaya Peningkkatan Mutu Guru Mata Pelajaran PAI)". Tarbawy: Jurnal Pendidikan Islam Vol. 7, No. 1 (2020).

Barirohmah, Subiyantoro. "ISO 9001:2008 Quality Management System In Education". Nazhruna: Jurnal Pendidikan Islam. Vol. 4, No. 2 (2021).

Fattah. Nanag, 2000. Landasan Manajemen Pendidikan. Bandung: Remaja Rosdakarya,

ISO 9001:2008. Document Development Complain Manual ... hal. 30.

Listyo Prabowo. Sugeng, Listyo Prabowo. Implementasi Sistem Manajemen Mutu ISO 9001:2008 (Malang: UINMalang Press. 2009).) Hal. 5768

Maksum, Nur. "Pengaruh Implementasi Siatem Manajemen Mutu (ISO) 9001:2008 dan Kepemimpinan terhadap Peningkatan Kinerja 
Guru di SMK Negeri 1 Jombang". Jurnal Revitalisasi: Jurnal IImu Manajemen, Vol. 5 No. 2 (2016).

Moleong, 2014. Metodologi Penelitian Kualitatif. Bandung: Remaja Rosdakarya Offset.

Muhlisin. Pengaruh Kinerja Guru Menyongsong Masa Depan, dalam

Mulyasa. E, 2007. Manajemen Berbasis Lembaga Pendidikan (Bandung: Remaja Rosdakarya. Nungkiastuti, Fauzia Damas, Kusumawardhani, Amie. "Implementasi Manajemen Berbasis Sekolah Tingkat SMA dalam Pengelolaan Manajemen Mutu ISO 9001:2008". Syntax Literate: Jurnal IImiah Indonesia, Vol. 6, No. 9 (2021).

Peraturan Pemerintah Repuplik Indonesia Nomor 19 Tahun 2005 Tentang Standar Nasional Pendidikan

Purwadi. 2012. ISO 9001:2008 Document Development Compliance Manual. Kediri: Media Guru.

Riadoh, Siti, Yuliati, Erlina. "Manajemen ISO (International Organization For Standardization) Di SMK
Muhammadiyah Prambanan". Jurnal Manajemen PendidikanDasar Menengah Tinggi (JMPDMT). Vol. 01, No.02 (2020).

Salaga, Syaiful. 2013. Kemapuan Profesional Guru dan Tegana Kependidikan.

Bandung:

Alfabeta. Cd.

Sulham. Muwahid, 2013. Model Kepemimpinan Kepala Sekolah dalam Meningkatkan Kinerja Guru. Yogyakarta. Teras.

Susanto, Ahmad. 2016. Konsep, Strategi dan Implementasi Manajemen Peningkatan Kinerja Guru. Jakarta: Prenadamedia Goup.

UUSPN No. 20 2003. Sistem Pendidikan Nasional (Jakarta: Asokadikta \& Durat Bahagia)

Zahroh, Aminatul. 2014. Totl Quality Management teori \&praktik manajemen untuk mendorong mutu pendidikan. Yogyakarta: Ar-Ruzz Media. 